\title{
Reading Hair as a Symbol to Understand Changing Gender Roles in "Rapunzel" and Rapunzel's Revenge
}

\author{
Suchismita Dattagupta*
}

\section{Abstract}

Fairy tales have always been captivating for young readers. Since most of the fairy tales have their source in oral folktales, they highlight traditional gender roles and create stereotypes. As Maria Nikolajeva (2003) states, fairy tales reflect its own time and society. Evolution in readership has led to a change in these reflections. "Rapunzel" is one of the most iconic fairy tale characters and she is known for her long golden hair. Hair carries symbolic implications and is often associated with femininity, and exhibits how societal control influences how she/he wears their hair. By the transformation of her hair in the adaptations, the authors depict a change in the traditional gender roles. Rapunzel's Revenge by Shannon and Dean Hale will be read as a counter-narrative to Grimm's "Rapunzel" to investigate the changes in the fairy tale genre and enable a reading of the changing hair symbolism in order to understand the change in gender roles and identity.

Keywords: Fairy Tales, Adaptation, Gender roles, Hair symbolism, Identity, Social conformity

\section{Introduction}

Fantasy fiction in the form of fairy tales is a popular literary genre often designed to instruct and entertain children. Apart from

* Research Scholar, University College Dublin, Republic of Ireland; suchismitadg123@gmail.com 
fuelling the imagination of the young readers, the medium becomes a powerful tool for children to imbibe knowledge about their society. Despite being rooted in oral traditions, fairy tales received criticism from moralists, who termed these tales as "juvenile literature" (Grenby, 2014). These fictional tales were supposed to perverse the mind of the young and the innocent. While there was criticism towards this genre, it is interesting to note that during the 18th century, fairy tales saw a rise in children readership. To keep their books viable in the market, by the mid19th century, authors started incorporating two dominant forces in the genre; that of realism and didacticism, and fantasy and fiction. The amalgamation of these two aspects helped children enjoy the world of fairies and goblins while learning a lesson.

With the transformation of children's literature, Jacob and Wilhelm Grimm's first edition of Kinder und Hausmärchen or Children's and Household Tales was published in 1812. It was later edited and republished in 1857 since the stories were too risque for children. Marina Warner elucidates in "After 'Rapunzel"" that "fairy tales" need not only be stories about the magical world of enchantment. They were often stories about the experiences and knowledge derived from voiceless people in the society, women, and children. The "feminist fairy tale debate" (Joosen, 2011, p. 5) believed that fairy tales have a direct effect on the dreams and lives of women. Feminist critics argue that the image of the woman constructed by these fairy tales is one of a passive, weak heroine, who is dependent on the prince. With the passage of time, modern authors have tried to rewrite the identity of the passive princess. The modern texts have kept in mind the sensibility of the current audience and made changes to the traditional tale.

Rapunzel is one of the most popular fairy tale characters. While there are other equally memorable characters, Rapunzel with her long golden hair has always garnered the attention of the readers. Ever since the 1812 edition, "Rapunzel" has appeared in many variants. While Rapunzel's hair becomes a part of her identity, the change in the reader's attitude, with changing time, has brought in some modification in the adaptations of Grimm's "Rapunzel."

Hair is one of the primary images in the story of Rapunzel. As stated by Synnott (1987), hair is a malleable aspect of the human 
body and an important vehicle for conveying symbolic changes. Women's hair is a visual indicator of the changing understanding of feminine identity. Hair can send a social message, both positive and negative, which brings forth issues related to the femininity of hair to the forefront of the cultural discourse. Hair imagery is used in literature to communicate and explain the tension between individuality and social conformity. Hair is read as a symbolic expression of femininity and offers an important understanding of the effects of individual and social forces that constructs and subverts femininity and the fashioning of the female body in literature. The central preoccupation with hair is because it is simultaneously private and public. It is visible to everyone while at the same time being a very personal aspect of the human body (Weitz, 2001, p. 667).

This paper will aim at seeing how the fairy tale "Rapunzel" manifests itself in the newer texts that were written for young readers. Jack Zipes (2011) states that fairy tales proved to be an excellent means to both propagate for and to question the official dogmas. With Rapunzel's Revenge as a counter-narrative, the focus would be on hair symbolism and the way in which it helps transform the female identity. The change in the way hair is depicted in the traditional narrative and the modern adaptation will be read to understand the changing gender roles.

\section{Countering traditional narratives}

The fairy tale genre has come a long way since the time it was considered inappropriate for children. The tales over the years have become appropriate to the sensitivity of children. With the advent of technology, the printing techniques further transformed the fairy tale genre. The traditional narrative gave way to picture books and graphic novels while keeping the traditional fairy tale plots intact. The traditional narratives have now become hypertexts. Hypertext, as defined by Ted Nelson in 1965, is a new kind of textuality that helps "transcend the linearity of the written text." (Hammerberg, 2001) The fairy tales are now published in books, where the written text accompanies images and photos. The hypertext extends the meaning of the story beyond the written text. They show how the 
fairy tale as a genre has evolved to better incorporate the issue of hair symbolism and the sensitivity of the readers.

This paper would try to compare the 1857 version of Grimm's Children's and Household Tales to the 2010 adaptation, Rapunzel's Revenge by Shannon and Dean Hale (2008). Rapunzel is weaved as a traditional narrative and as such, it is part of a landscape that is well known. The audience is familiar with the nuances of this narrative and knows the outcome of the tale and derives satisfaction from the familiarity of it. The authors in the modern times are taking a conscious step in trying to move away from the tradition to open the space for alternatives. Shannon Hale makes a conscious move away from the fairy tale of Rapunzel. While the background of the story remains the same, the situation is slightly different in Rapunzel's Revenge. Rapunzel in Rapunzel's Revenge was taken away from her parents by the wicked Gothel, who is a rich landowner. She is proficient in magic and has plunged the entire country into a drought. With no way to grow crops and survive, farm owners agree to pay Dame Gothel, double her share of the yield, to get a chance to use her growth magic. While Gothel's villa and the surrounding garden are teeming with lush green vegetation, the condition outside the high walls of Gothel's mansion is completely different.

The first thing that needs to be mentioned is that while the Grimm's edition is a third person narrative, which hardly gives any agency to Rapunzel, in Shannon Hale's Rapunzel's Revenge, it is Rapunzel herself, who starts with the narration. She is the one who introduces the readers to her world and has a voice. This seems like a conscious effort on the part of the author since Hale (2008) had made it very clear that she would not be creating the quintessential fairy tale princess out of Rapunzel in her book. Rapunzel here is someone who takes charge of things. She is not the one to sit and wait to be rescued by the prince from her towered confinement. Rapunzel starts the story of her life in the style typical of the fairy tales. She starts with "Once upon a time, there was a beautiful little girl" (Hale, 2008, p. 4). Rapunzel in the original fairy tale is a princess and the mansion that the viewers see in Shannon and Dean Hale's graphic novel also indicate that Rapunzel might be a princess but instead the readers encounter a little girl who is 
swinging from any awning, only to crash land into a pool of water. Rapunzel's Revenge eliminates the whole idea of the perfect and dainty princess the moment readers reach the panel where Rapunzel peers out of the pool and states, "That's me there." (Hale, 2008 , p. 5) Her hair is matted and wet, and the readers realise that Rapunzel is a clumsy little girl.
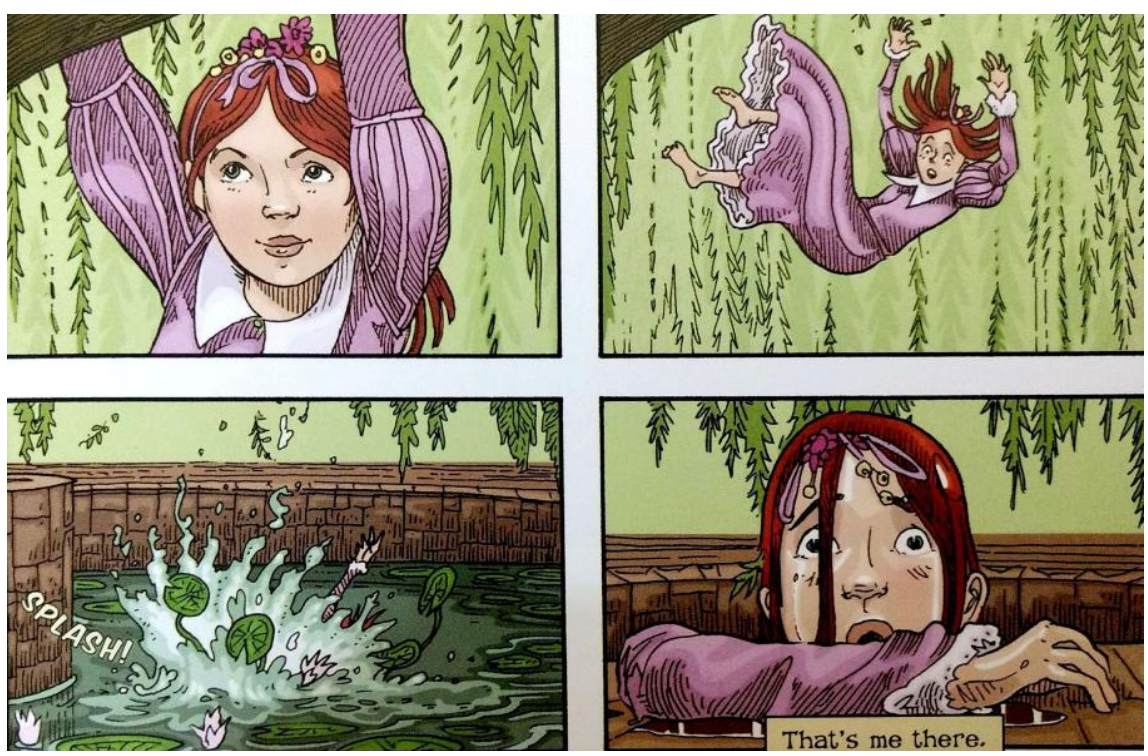

Image 1. Rapunzel's entry in the book, where she doesn't appear to be the quintessential princess. Retrieved from Rapunzel's Revenge (2008)

Rapunzel is the narrator of Shannon and Dean Hale's Rapunzel's Revenge and she introduces the readers to her world and life. She lives in a grand villa, with loyal servants and tasty food. Rapunzel goes ahead to say that she lives with her mother but then adds, "(o)r who I thought was my mother." (Hale, 2008, p. 6) The moment readers see this panel and look at Dame Gothel's expression, they know that something is not right. The panel immediately takes the readers back to the original plot of "Rapunzel" where Gothel had snatched Rapunzel away from her parents since they dared to take parsley from her garden. Hale makes the readers wait to find out more about Rapunzel's past. The narrative focusses on her present. Rapunzel introduces the readers to her life in the huge villa, with three stories and seventy-eight rooms. She has nothing much to do and hence counted all the 
thousand and twelve chairs. Rapunzel had a privileged life but there is emptiness within her. She could not understand why she would feel so incomplete and why she would have the recurring dream of two loving individuals. Mother Gothel would never be happy with the dreams that she had and would chide her for indulging in sadness.

In the Grimm's version, Rapunzel never realises who her parents are and why she has been kept shut in a tower. She is not given any voice. There is a complete lack of consideration that she might have some thoughts on her situation. On the other hand, Rapunzel in Rapunzel's Revenge is very curious and tries to find out what's on the other side of the wall of her palatial house. Finally, on her twelfth birthday, she decides to climb the huge wall and find out what's on the other side. She agreed to climb it even though Mother Gothel disapproves of it. After a difficult climb, Rapunzel comes face to face with the mines on the other side of the wall, and she is shocked. She is speechless and wants to know what was happening out there. This is when she encounters her mother, and it triggers in her the realisation that Mother Gothel had been lying to her for all these years and she decides to confront her.

Rapunzel in the Grimm's "Rapunzel" was kept away from society and there was always a clear demarcation between the social and individual spaces. "When she was twelve years old the witch shut her up in a tower in the midst of a wood, and it had neither steps nor door, only a small window above." (Grimm, 1993, p. 76) The Rapunzel in the modern retelling is an individual who connects with the reader from the first sentence whereas the reader of Grimm's fairy tale, looks up at Rapunzel from beneath the tower and never gets the opportunity to know her. Her hair comes to represent her, and it is not her individuality that helps the audience to remember her. Rapunzel of Rapunzel's Revenge, on the other hand, connects with the reader with her humour even before they get to find out how she can make use of her hair. Rapunzel introduces the reader to her world, exactly how she sees and perceives it. 


\section{Countering gender roles}

Unlike the linear narratives explored in traditional fairy tales as seen in Grimm's "Rapunzel," the graphic narrative in Rapunzel's Revenge, gives the readers the freedom to explore a narrative that is not limited to the so-called accepted roles of a woman. Rapunzel's action and body language in Rapunzel's Revenge exude confidence. The author makes a conscious step to move away from the stereotype and negates the image of the innocent persecuted heroine that is present in fairy tale narratives.

Karen E. Wohlwend in "Damsels in Discourse: Girls Consuming and Producing Identity Texts through Disney Princess Play" uses a mediated discourse analysis to depict how children internalise the image of the Disney princesses. The specific focus of her study is young girls who are fans of the Disney princesses. Wohlwend shows how children assume the identities and gender expectations from the dolls, storybooks, and films that they are exposed to. This study helps understand the gender stereotypes that are created through the fairy tale characters and the notions of gender performativity that they promote. Judith Butler in her work, "Performative Acts and Gender Constitution: An Essay in Phenomenology and Feminist Theory" says that gender is not a performance, rather it is a performativity and goes on to explain performativity as something that we often perform unconsciously. It is an act over which we do not have a freedom of choice. It is said that a child is aware of its sex only from the age of three. This is because she is made aware of her gender roles and can draw the distinction between the gender roles of the opposite sex.

Jerilyn Fisher and Ellen S. Silber (2000) talk about the influence of cultural expectations and the limiting sex-role stereotyping that is prevalent in classical fairy tales. Fisher and Silber (2000) also spoke about reconstructing traditional theories to include the developmental experiences of culturally diverse women, in "Good and Bad Beyond Belief: Teaching Gender Lessons through Fairy Tales and Feminist Theory." The traditional fairy tales offer "male fantasies" (Fisher \& Silber, 2000, p. 122) which restrict the vision of children, especially girls, about their social roles. To move away from the traditional narrative of the Grimm's and to appropriate 
the fairy tale for the audience of the 21st century, Hale brings in a powerful word. She uses the term "revenge" to show that Rapunzel is not a typical fairytale princess who will sit and accept what life must provide her with. Rapunzel in Hale's Rapunzel's Revenge heads to right all the wrong that had been done to her. She finds out the story of her past, unlike the original Rapunzel, who never found out about her parents.

The chief source of patriarchal power is the unquestioned acceptance of the narratives that have come down the years, and this is where Hales tries to bring about change. There is a need to study fairy tales from a "new woman centred socio-psychological understanding." (Dunn, 1996, p. 154). Hale gives the narrative power of her story to her heroine instead of the omnipresent narrator in Grimm's "Rapunzel." This step of Hale's in Rapunzel's Revenge is a way to show that the perception of gender identity in fairy tales has changed since the time Grimm Brothers came out with Children's and Household Tales. Analysis of "Rapunzel" and Rapunzel's Revenge highlights the changes in symbols. The change in the perception of gender identity sees Hale adapting the original tale to her imagination and making conscious changes in the symbols that will instruct the young readers. The readership of the fairy tales has changed between 1857 and 2008. Children in the 21st century are more aware of their roles in society, and the ideas of social roles associated with conformity and beauty have undergone massive changes. They have in fact been challenged by generations.

Rapunzel in the Grimm's fairy tale accepts her confinement. She never questions the wicked witch about her past and neither does she try and change her situation. Rapunzel in Rapunzel's Revenge is not one to keep quiet. She realizes that Mother Gothel had lied to her and did not think twice before blaming her for lying. She charges her with the words, "You lied to me." (Hale, 2008, p. 19). Her expression makes it evident that she is not one who would let go of things easily and is determined to find out the truth. 


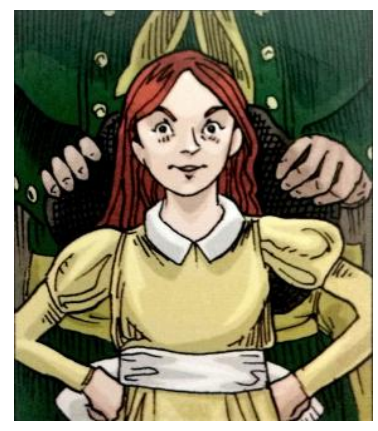

Image 2. Rapunzel's demeanour is different from the traditional character. Retrieved from Rapunzel's Revenge (2008)

Her behaviour ultimately backfires and she is imprisoned in a magical tree-tower in the middle of the forest. She tries to lie and escape the tree but when Mother Gothel realises her plan, she does not think twice before speaking her mind to Mother Gothel. Rapunzel says, "I guess I'd never stood up to Mother Gothel... I was scared spitless, but I knew that I could not pretend anymore." (Hale, 2008, p. 32)

She realises that the incident causes more trouble for her since the opening to the tree-tower keeps shrinking and food stops appearing. However, all four years in captivity had left her with long red hair and with nothing much to do she learned how to make use of the hair as a lasso and swing. Rapunzel decides to escape the tree-tower by swinging down with the help of her hair rope. After a lot of effort, she does manage to "land triumphantly on the forest floor" (Hale, 2008, p. 35) and begin an epic adventure. Rapunzel tames a wild boar and is on her way out of the forest when a strapping young man ends up killing it, to rescue her.

Children throughout the ages have grown up reading about the prince who rescued Rapunzel from her miserable living up in the tower. As Hoffman states in his book, From Modernism to Postmodernism: Concepts and Strategies of Postmodern American Fiction, the role of the prince, is to rescue from outside what cannot be liberated from inside. Hale turns this very concept to the head when it comes to her depiction of the prince in Rapunzel's Revenge. The prince assumes that he had helped Rapunzel when she hints disapproval. Instead of rescuing Rapunzel from her predicament, he ends up snatching her wild boar, which was her only chance of 
exiting the forest. The prince in Grimm's "Rapunzel" is a romantic who falls in love with Rapunzel because of her sweet voice and goes on to have an affair with her. Hale does not get into the romantic side of the tale. She unpacks the romantic notion of prince charming going on an adventure to rescue the damsel in distress which has been used in earlier versions of the tale. Men tend to believe this notion and assume that women want to be rescued. In Rapunzel's Revenge, the prince says he was getting bored at his farm and had hence followed the tales of a beautiful maiden trapped in a high tower. Hale's Rapunzel is not one to sit tight waiting for the prince to come along. She asks the strapping young man if he was heading to "help her" (Hale, 2008, p. 41) but the prince ends up saying "I can't actually rescue her, of course. The word is she's Mother Gothel's pet and I won't risk crossing the old lady. But I can tell her I'm going to rescue her. She's bound to be too naïve to know the difference, and it'll be such fun in the meantime." (Hale, 2008, p. 41)

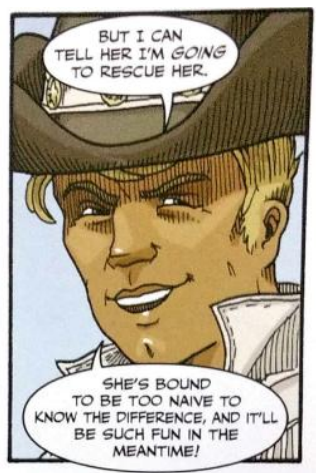

Image 3. Countering the character of the fairy tale prince, to show that Rapunzel isn't dependent on him. Retrieved from Rapunzel's Revenge (2008)

These words are a direct dig at the world of the fairy tales and the notions that children inculcate through them. The fairy tale narratives have always reflected a cultural expectation of femininity. This invariably reflects the "dominant ideology of female dependency" (Conrad, 1999, p. 129). As a counter-narrative that brings forward an alternate version of the world that the readers are familiar with, Rapunzel might have started her story with the "once upon a time" trope but she ends it with the way she 
sends the prince away. Rapunzel makes it clear to the readers that "This is where the "once upon a time" part ends..." (Hale, 2008, p. 41).

\section{Choice of narrative form}

It becomes evident while readers enjoy Rapunzel's story that Rapunzel's Revenge is a counter-narrative to a traditional fairy tale. Hale picks out instances from the original fairy tale plot and makes sure she changes and rewrites them to suit the sensibility of her readers. The first sign of a counter-narrative can be seen in the genre of the text. Hale makes use of the graphic narrative. The narrative has always been used to state the dark and violent world. It is associated with crime and action but Hale establishes that the world of the graphic novel is not restricted to young boys. While talking about her decision to work on a graphic novel for her adaptation of "Rapunzel," Shannon Hale said that having read about superheroes, she decided to give girls a heroine that they can look up to. Hale also decided to use the character to venture into a genre that was dominated by male readership.

The counter-narrative help readers develop an innate idea of the traditional narrative and understand the jarring differences in the two texts. The readers think and talk about Rapunzel's Revenge's departure from the traditional narrative of "Rapunzel" and why it is a necessity to look at the text in a different light. Fairy tales in the hands of women were always meant to be counter-narratives. D'Aulnoy started a trend when she included her fairy tale, "The Isle of Happiness" in the novel Histoired'Hippolyte, comte de Duglas in 1690. The nymphs she used in her tales were not fairies but they bore a resemblance. D'Aulnoy very clearly establishes in her stories, the intervention of the fairies to make up for what is lacking in the real world and the human nature. (Zipes, 2011, p. 223). With d'Aulnoy's popularity, there was a surge of fairy tale writers, especially among the women author. The 17th century saw authors like Marie- Jeanne Lhéritiet's Oeuvres Mêslées, published in 1696, Charlotte Rose Caumont de La Force's Les contes des contes, published in 1698. Henriette-Julie de Murat, Catherine Durand, and Comtessed'Auneuil were some of the other authors who published their own "contes des fées" during the time. It was 
evident that the use of the term was a declaration of resistance. Zipes notes that in no other period of literary history that "so many fairies like powerful goddesses were the determining figures of most of the plots of fairy tales written by women, and also by some men." (2011, p. 224)

There is a reason why so many female authors came forward to write stories and term them as fairy tales during the 17th and 18th century. The French women who wrote these stories were part of the literary salons where they would read and share their stories before they were given for publication. The private salons provided them the scope to demonstrate their talent at a time when women did not enjoy much freedom in the public sphere. The fairies included in their stories marks their resistance under the conditions in which they lived. They had strict regulations and manners they had to adhere to. It was only in the fairy tale world, where they were unsupervised by either the Church or the state, that they could show an alternative world, talking about their desires. Even scholars like Holly Tucker and Anne Duggar have come out in support of the salon culture being a primary stimulation to the female authors of the fairy tales. The salons helped them establish a specific code and the tales gave shape to a new idea which was intended to "transform the relationships between men and women" (Zipes, 2011, p. 225).

\section{Transformation of the princess}

Keeping the tradition of the counter-narrative intact, Shannon Hale and Dean Hale go forward to create an alternate world for Rapunzel. It has been stated time and again that children are sensitive to the stories they read, and it is wrong when they read about passive heroines who need a prince to come and rescue them. Hale's twist to the classic fairy tale stops Rapunzel from becoming a passive heroine. She is a vigilante hero who gallops "around the wild and western landscape, changing lives, righting wrongs and changing (the) world forever." (Hale, 2010) James Blasingame in his review of Rapunzel's Revenge, in the Journal of Adolescent \& Adult Literacy, talks about how the traditional trope of the blonde princess is transformed into a tomboy in her pants, shirt, vest and cowgirl gear to take on an adventure. Blasingame 
points out that Shannon Hale was careful not to sexualize Rapunzel. Instead of the typical blonde princess, Rapunzel is a skinny red-head. They paid special emphasis on how Rapunzel's character is perceived in the story and in keeping her casual and ordinary, there are no men in the story who is attracted to her. She is not the typical fairy tale character that sits locked up and attracts men with her beauty and singing.

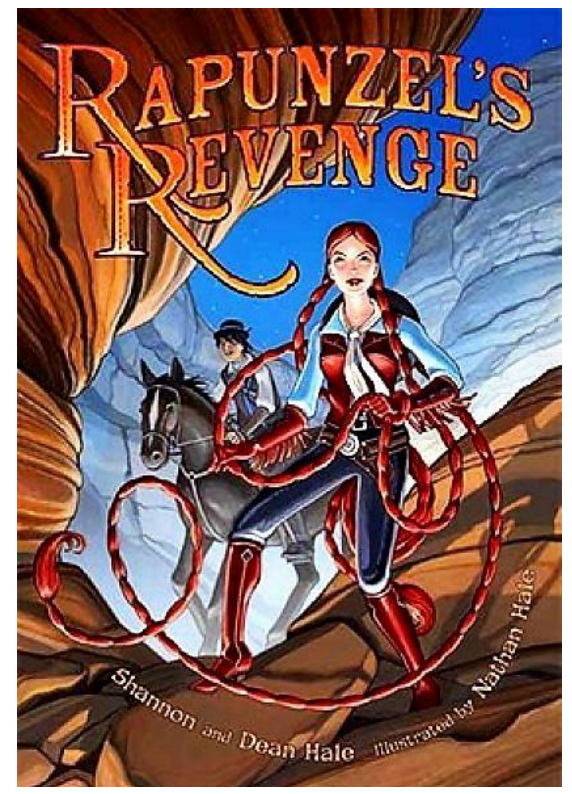

Image 4. Cover image of the graphic novel. Depicting Rapunzel as a redhead in cow-boy attire Retrieved from Rapunzel's Revenge (2008)

\section{Changing hair symbolism}

Hair has always been defined in detail when it comes to female characters and the same is followed by the Grimm Brothers in the case of Rapunzel. The first instance when the readers are acquainted with Rapunzel, it is her beauty that is highlighted"Rapunzel was the most beautiful child in the world... Rapunzel had beautiful long hair that shone like gold" (Grimm, 1993, p. 76). Rapunzel's hair in the tales of Grimm serves the character no purpose apart from enhancing her beauty and becoming a performance of gender role as the beautiful damsel. It is used by 
the witch and the prince, but it does not serve the owner any purpose. Hale changes this in Rapunzel's Revenge. Her hair grew as she was confined in the tall tree-tower by Mother Gothel. In her boredom, she decided to use it to pass her time and asserted "There were three books in the tower. By the second year, I had them pretty well memorized. And then I started to find other ways to pass the time. To keep from going batty, I made use of my dratted hair." (Hale, 2008, p. 30)

She used it as a skipping rope, a fly swatter and when it was long enough, tried to use it as a rope to lower herself down. It was short initially, but it grows enough for her to escape. Hair was initially a source of control. For Rapunzel in Grimm's tale, her hair and beauty caused her to be confined in the tower, away from the gaze of the world, but in the case of Hale's Rapunzel, the hair becomes her way to escape the tower and gain freedom. Rapunzel says that she was beginning to worry that she was as "naïve and helpless" as the "rifle-toting ninny" "prince-charming" had expected her to be, but she instinctively ends up using her hair when she sees Jack being attacked (Hale, 2008, p. 43). She says, "I did not think twice before pulling out my braid" (Hale, 2008, p. 45). She does not try to be a hero, but she is not a raggedy little girl who would stand and watch.

Rapunzel realizes that her hair can be used as a weapon and uses her lasso lessons from her time at the Gothel mansion to attack enemies and tame wild beasts. When Rapunzel and Jack are about to tackle the coyotes in Pig Tree Gulch, Rapunzel jokes about using her "feminine wiles" (Hale, 2008, p. 67) but ultimately uses her hair to drive the coyotes away. She uses her hair to kill the frightening serpent as well and gets her hand on the pick that could break even the unbreakable. Rapunzel in Rapunzel's Revenge is never shown to be careful of her hair or use it as a seat of her beauty. Rapunzel is expressive about her discomfort with the long hair. She says "...try hauling around twenty feet of hair. It's likely to break my neck" (Hale, 2008, p. 74). She carries it wrapped around one her shoulder like rope and she uses it as a weapon instinctively. After Rapunzel and Jack escape from Macmillan's men and the jail, the two become wanted convicts, and there is a huge poster with Rapunzel's face on it. Rapunzel is charged with horse thieving, kidnapping, jail 
breaking and for using her hair in a fashion that is different from the way nature intended her to use it. The accompanying image in the graphic novel depicts Rapunzel holding her braid, like a noose.

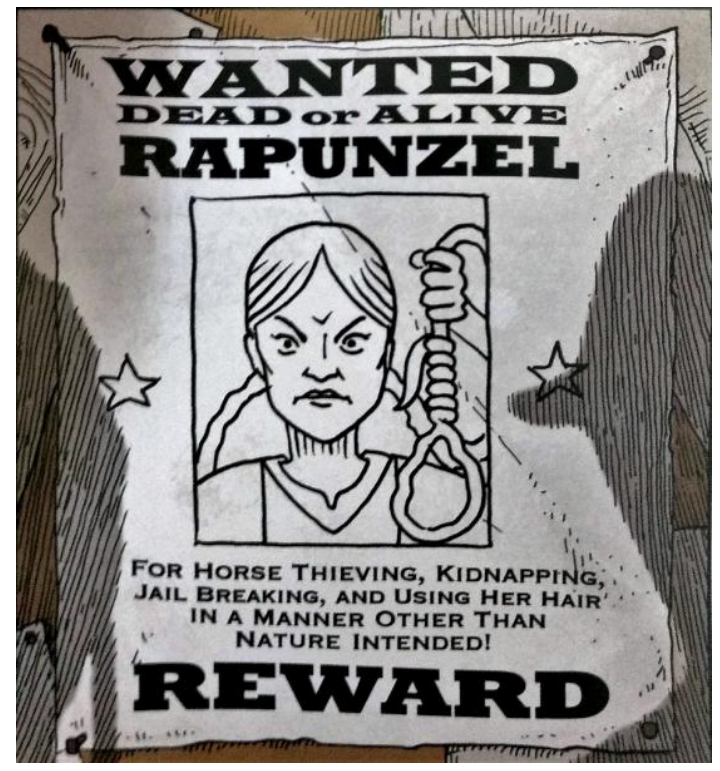

Image 5. Poster showing how Rapunzel uses her hair in a manner that is socially unaccepted. Retrieved from Rapunzel's Revenge (2008)

Appearance plays a primary role in determining how an individual is going to be perceived in society and one of the basic physical traits that help determine personality traits is hair colour. As Druann Maria Heckert and Amy Best (1997) have said: "Hair is an important aspect of how people define themselves and how other people define them" (p. 365). It is important to understand that hair colours go a long way in creating stereotypes. The primary colours used in Rapunzel's Revenge are red and orange. It is no secret that red-heads play an important role in various literary works and they are primarily associated with spirited and temperamental individuals who are mischievous and imaginative. It should be noted here that Shannon and Dean Hale consciously created a redhead as their protagonist since it countered the traditional golden hair of Rapunzel. 
Given that hair colour has been associated with personality traits the red hair is an important symbol when it comes to rewriting Rapunzel's identity and gender roles. Chelsea Anderson (2015) in her dissertation, The Importance of Appearances in Literature: What Does It Mean to Be a Redhead in Literature? depicts how redhead is used as a trope in literature. Redheads have been associated with "magical or the mystical world." Another study conducted by Beddow, Hymes and McAuslan found that individuals who are blonde, are often considered to be "dumb" (Anderson, 2015, p. 5). This takes us back to the typical idea of the fairy tale princess, the damsel in distress, who is incapable of escaping her current situation and needs a prince to help her out. This labelling theory propounds the idea that there are "certain symbols [that] become deviant because of the stigmatisation of those symbols" (Anderson, 2015 , p. 6). The same way that individuals with blonde hair are stereotyped across culture, redheads are also stigmatised throughout history and are associated with forms of deviance. Redheads are usually considered to be the symbols for the weird, the clown and the intellectually superior. Given that Rapunzel's Revenge is adapting the original fairy tale to tell a story with a modified ending that suits the sensibility of the current audience, there is a clear idea that the redhead here is associated with intellectual superiority, someone who is spontaneous and imaginative. This conscious attempt at trying to replace the original blonde fairy tale princess with a redhead is a motif that the author has consciously resorted to.

As the adventures of Rapunzel and Jack continue in Rapunzel's Revenge, the readers realise that Rapunzel is braver and more capable than Jack in most of the situations. As the story progresses, she finally confronts Mother Gothel and almost succeeds in strangling Mother Gothel's muscle man, Brute, with her hair, but his sheer strength overpowers her, and she ends up getting her hair chopped. Rapunzel in Grimm's tale is not shown to be vocal about having her hair cut or being cast off into the forest. She has no agency at all. This is changed in Rapunzel's Revenge. The tier showing Mother Gothel snip off her hair depicts Rapunzel looking distraught and helpless. It was her hair that brought her this far and ensured that she could fight Mother Gothel and her evil deeds, and she almost senses defeat. She stares at the long strand of red 68 
hair lying on the floor and it almost indicates an end to Rapunzel's adventure. However, it needs to be remembered that Shannon Hale and Dean Hale are not out to create a passive heroine. The counternarrative has to rewrite the character of the passive Rapunzel, and this is when we see Rapunzel look up to glare at Mother Gothel to say, "Hardly" (Hale, 2008, p. 129) when Gothel asks her if she was “...submissive. Ready to obey my every word." (Hale, 2008, p. 129)
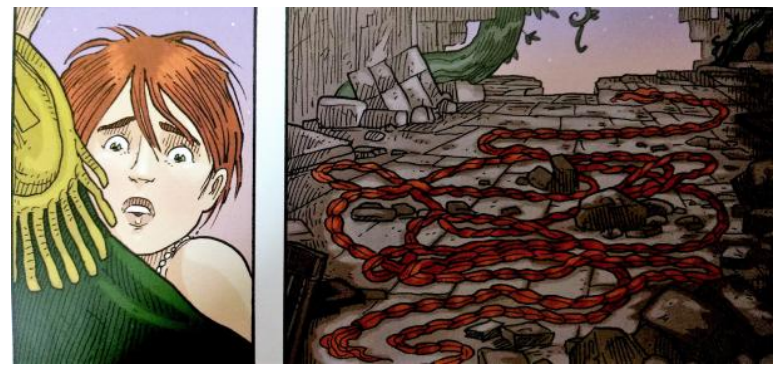

Image 6. Horror in Rapunzel's face depicts her emotion on having her hair cut. Retrieved from Rapunzel's Revenge (2008).
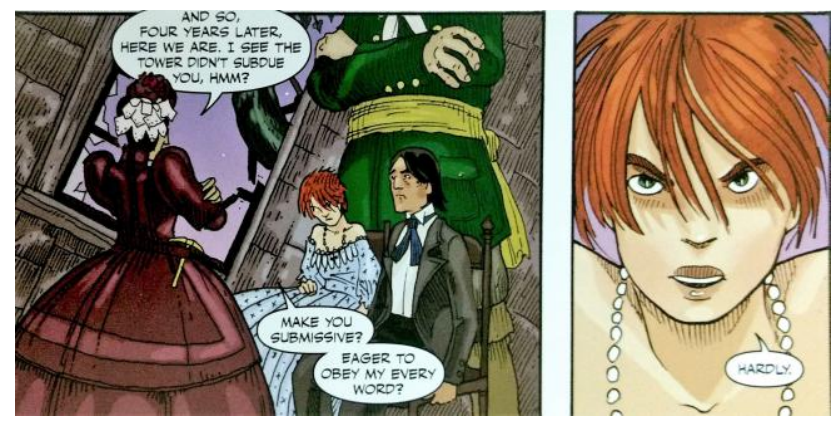

Image 7. Rapunzel overcomes hair defeat to show that she is more than just her hair. Retrieved from Rapunzel's Revenge (2008).

Despite her hair being cut by Mother Gothel, she refuses to bow down to her. Her strength is not limited to the hair. The panel depicts an individual's refusal to bow to societal pressure. She does not mind being confined to another one of Mother Gothel's magical tower if she would spare Jack. Rapunzel is smart enough and ends up using the magical pick to break the totem that Mother Gothel used to unleash her magical power. In the end, we see Rapunzel use her hair as a rope to go up the clock tower to look at the green countryside. Hale brings in the chant used in "Rapunzel" where the 
witch would ask Rapunzel to let her hair down so that she could climb the tower. Jack asks Rapunzel to let her hair down so that he could go up when there was no other way to do so. The two texts clearly highlight how hair symbolism in texts like "Rapunzel" and Rapunzel's Revenge has gone ahead to show the dialectic between individual identity and social conformity. There is a marked change in how hair symbolism was used to serve the purpose of the dominating forces in society and how in the later adaptations of the fairy tale, the authors have made a conscious step to make sure that hair symbolism goes ahead to uphold individual identity and subverts societal dominance and authority. This goes on to show the counter-narrative of Rapunzel's Revenge and how it takes a step forward in addressing the bigger picture that the dissertation aims at achieving.

\section{Conclusion}

Hair has always been the focus of much preoccupation and the way a person wears their hair can go ahead to describe the individual's identity, beliefs, and sentiments. Being malleable, hair becomes an essential vehicle for conveying symbolic meaning. It helps to understand how the social and individual forces of the time are constructing the female body and femininity. Hair was meant to be the seat of beauty and femininity and Shannon Hale depicts how Rapunzel broke that notion when she used her hair in a fashion that nature did not intend her to do. A girl's hair is meant to be adorned with flowers and should go on to accentuate her beauty. However, Rapunzel was not one to adorn her hair. She used it for survival and till the end kept using it as a weapon and a rope. Rose Weitz says that hair is both private and public. It is private because it is part of the human body, and it is public since hair has been used by society to establish control over an individual. Shannon Hale made it very clear that she did not want to narrate the story of a typical fairy tale princess and hence the first thing she did was give her red hair. Repeating the symbolic implication of the redhead in literature, Shannon Hale establishes the intellectual superiority of the Rapunzel's character in Rapunzel's Revenge as compared to the typical fairy tale princess. The counter-narrative of Rapunzel's Revenge has a cover illustration depicting Rapunzel in 
cowboy attire, with her long red braid held like a lasso. She is standing and looks like she is ready to attack. The readers start Rapunzel's Revenge with the idea that Rapunzel would not be a character that they have heard of. She is different from the princess who sat in the tower, singing. Rapunzel's Revenge highlights the attempt made by authors of recent Rapunzel adaptations to create a different worldview for the readers. There is a need to change the idea of the princess. Children readers are impressionable and do not take the time to pick up ideas and notion. Given the current urgency in conversations about envisioning a world with equal rights and privileges, a fairy tale where princesses are still stuck in the ancient world of conforming to social pressure by foregoing their individual identity is hardly convincing. They need to be given a voice and what better way to give Rapunzel a voice and with the one symbol that defined her across generation- her hair.

\section{References}

---. (2014, October). Rapunzel's Revenge. Retrieved from http://www.squeetus.com/stage/books_rap.html

Anderson, C. (2015). The importance of appearances in literature: what does it mean to be a redhead in literature?. Unpublished Honours Theses. Retrieved from https://aquila.usm.edu/honors_theses/274/

Blasingame, J. (2010). Interview with Shannon Hale about Rapunzel's Revenge. Journal of Adolescent \& Adult Literacy, 53(6), 518-520. Retrieved from http:/ / www.jstor.org/stable/25614598

Butler, J. (1988). Performative acts and gender constitution: An essay in Phenomenology and Feminist Theory. Theatre Journal, 40(4), 519-531. DOI: $10.2307 / 3207893$

Conrad, J. (1999). Docile bodies of (im)material girls: The fairy-tale construction of JonBenet Ramsey and Princess Diana. Marvels $\mathcal{E}$ Tales, 13(2), 125-169. Retrieved from http:/ / www.jstor.org/stable/41388540

Dunn, L., \& Jones, A. (1996). Embodied voices: representing female vocality in western culture. Cambridge, UK: Cambridge University Press.

Fisher, J., \& Silber, E. (2000). Good and bad beyond belief: teaching gender lessons through Fairy Tales and Feminist Theory. Women's Studies Quarterly, 28(3), 121-136. Retrieved from http:// www.jstor.org/ stable/40005478 
Grenby, M. O. (2014). Fantasy and Fairy Tale in Children's literature. Retrieved from https://www.bl.uk/romantics-and-victorians/ articles/fantasy-and-fairytale-in-childrens-literature

Grimm, J., \& Grimm, W. (1993). Grimm's Fairy Tales. (L. Crane, Trans.). Knoxville, TN: Wordsworth Classics.

Hale, S., \& Hale, D. (2008). Rapunzel's Revenge. (N. hale, Illus.). London, UK: Bloomsbury Publishing P L C.

Hammerberg, D. (2001). Reading and writing "Hypertextually": children's literature, technology, and early writing instruction. Language Arts, 78(3), 217-216. Retrieved from http://www.jstor.org/stable/41483140

Heckert, M., \& Best, A. (1997). Ugly duckling to swan: Labeling Theory and the stigmatization of red hair. Symbolic Interaction, 20(4), 365-384. DOI: 10.1525/si.1997.20.4.365

Hoffman, G. (2005). From modernism to postmodernism: concepts and strategies of Postmodern American fiction. Amsterdam, Netherlands: Rodopi.

Joosen, V. (2011). Critical and creative perspectives on Fairy Tales: A intertextual dialogue between Fairy-Tale scholarship and Postmodern retellings. Detroit, Michigan: Wayne State University Press.

Nikolajeva, M. (2003). Fairy Tale and Fantasy Fiction: Archaic to Postmodern. Marvels $\mathcal{E}$ Tales, 17(1), 138-156. Retrieved from http://www.jstor.org/stable/41389904

Synnott, A. (1987). Shame and glory: A Sociology of hair. The British Journal of Sociology, 38(3), 381-413. DOI: 10.2307/590695

Warner, M. (2010). After 'Rapunzel'. Marvels \& Tales, 24(2), 329-335. Retrieved from http:/ /www.jstor.org/stable/41388959

Weitz, R. (2001). Women and their hair: seeking power through resistance and accommodation. Gender and Society, 155, 667-686. Retrieved from http://www.jstor.org/stable/3081969

Wohlwend, K. (2009). Damsels in discourse: Girls consuming and producing identity texts through Disney princess play. Reading Research Quarterly, 44(1), 57-83. Retrieved from http:// www.jstor.org/stable/20304573

Zipes, J. (2011). The meaning of Fairy Tale within the evolution of culture. Marvels $\mathcal{E}$ Tales, 25(2), 221-243. Retrieved from http:// www.jstor.org/stable/41389000 